\title{
A Study of Waste Management of Households in Ulaanbaatar Based on Questionnaire Surveys
}

\author{
G. Delgermaa and T. Matsumoto
}

\begin{abstract}
As a result of the increasing Mongolian population, municipal solid waste, its kinds, the area affected, and environmental deterioration have also increased. The aim of this paper is to present an analysis and results of surveys and interviews used to gather information on municipal solid waste generation, composition patterns and their distinctive features. Based on the gathered data, the authors analyzed the current municipal waste generation conditions in Ulaanbaatar City, the capital of Mongolia, and identified the recycling management difficulties. The result of the study shows that separating the recyclable garbage before transportation to dumping sites reduces the amount of garbage transported by $30-40 \%$, lowering transportation costs and environmental pollution in Ulaanbaatar City.
\end{abstract}

Index Terms-Waste management, classification of waste, questionnaire survey, ulaanbaatar.

\section{INTRODUCTION}

In order to live in a healthy environment and reduce the usage of natural resources, people around the world are following the principles of protecting the natural surroundings, reducing the amount of waste, and classifying and recycling the disposals. Especially the highly developed countries with industrial and technological advances incline toward recyclable packages for their products. Countries such as Japan with huge factories recycle almost $99.9 \%$ of their industrial waste.

One of the first critical steps in the process of developing a reliable waste management plan requires the performance of a waste characterization analysis [1].

Ulaanbaatar has a few landfill sites in the mountains outside of the city. These landfills have no facilities for treatment or to prevent trash scattering or leakage; soil is packed down over wastes after they are burned. Incineration is normally in the open, allowing smoke and fly ash to settle over the city and "ger" villages. The incineration of many kinds of wastes gives the rise to concerns about the de novo synthesis of dioxins, and the contamination of soil, crops and livestock by these and other hazardous substances [2].

The outcome of the research in 2012 indicated that there was 1000-1300 tons of waste being produced in Ulaanbaatar City every day, $89.5-92.2 \%$ of which was transported to dump sites without being classified and buried immediately using the landfill method. Only $3.2 \%$ of the total waste went to recycling facilities and the remaining amount was waste that was thrown out into the surrounding environment illegally.

Manuscript received May 23, 2015; revised July 23, 2015.

The authors are with the University of Kitakyushu, Japan (e-mail: v4mac006@eng.kitakyu-u.ac.jp).
These values show that current system of waste management is still underdeveloped and is in dire need of immediate attention and improvement, especially in Ulaanbaatar city [3].

Lacking the proper facilities to classify waste products in Mongolia, three large-sized and vast numbers of small-sized dumps have emerged in the capital city of Ulaanbaatar today. This has led to many environmental problems such as water pollution, soil contamination and environmental pollution.

In order to dispose of the waste, huge amounts of waste are transported and burned every day without classification. However, even with all this burning, 3 large dumps and several small dumps have emerged in Ulaanbaatar City and more than 200 scavengers, most of them living in the dump sites, collect recyclable waste products, including bottles, cans, plastic bottles, iron and old electronic devices in severely toxic conditions. These scavengers sell the collected items to waste transfer centers. From there, all those recyclable waste products go to very limited, low power recycling plants and the remaining items are exported to China.

There are 173 trucks used for solid waste transportation in Ulaanbaatar City, but over 30 percent of them are old trucks outdated for use [4].

Although, there are significant improvements in solid waste management in Ulaanbaatar, there remain some major problems. Ulaanbaatar city consists of apartment and ger areas. The ger areas have poorly developed infrastructure, not connected to central heating and water supply and have low-levels of service provision. It is estimated that over 45 per cent population of ger areas is poor. Municipal Solid Waste Management still lacks capacity and effective methods of regulation. Governmental subsidy is insufficient, making the Municipal Solid Waste Management system solely dependent on waste collection fees from citizens, however only around $42 \%$ of the households in the ger areas pay the fee. Consequently, the financial situation is the key part that needs to be secured in order to maintain the service provision to these socio-economically vulnerable ger areas [5].

In some cases, especially in remote sites, Formal garbage collection is infrequent and unpredictable; residents dispose of most household waste themselves - usually by dumping it outside their houses, on hills, in yards, and alongside roads and waterways [6].

This paper is composed of five parts, including this introduction. The second part briefly describes the research objectives. The third part describes the methodologies used in the research. The fourth part describes questionnaire procedures. The fifth part describes the results and provides discussions based on the survey and analysis, and in a sixth part the overall study will be summarized. 


\section{RESEARCH OBJECTIVES}

The research purposes include the following:

Identification of amounts, composition patterns and types of household municipal solid waste per day in the "Ger" area, which is the Mongolian traditional tent and apartment area in Ulaanbaatar City, and recycling flow by means of a site survey.

\section{Methodologies}

In order to design a solid waste management plan properly, the first step consists in defining the waste generation and composition pattern of the city. The waste generation and composition patterns may vary around the city and over time [7].

The authors carried out a study based on two methods for collecting data, a questionnaire survey and interviews of residents, industrial sites and companies, and identification of waste amounts and types in 18 households.

The questionnaire survey was conducted among 400 citizens, including students of National University of Mongolia, Mongolian University of Science and Technology, University of Agriculture of Mongolia, andt employees of "Narantuul” International Trade Center and "Orgil” Shopping Center.

Impressions about current waste management in the city, key issues such as recycling management, environment pollution, and identification of waste features depending on the season were also collected.

The aim of the household survey was to collect data on amounts and types of solid waste in each household. The household survey was conducted in 18 households ( 8 of them living in traditional tents or "Ger" and 10 households living in modern apartments) located in the $14^{\text {th }}$ and $15^{\text {th }}$ sub-districts of Bayanzurkh district in Ulaanbaatar City. The households were each given the same instructions about how to keep and separate daily waste products generated in the households.

The inhabitants took notes about amounts and types of daily solid waste for two weeks. The inhabitants also measured the weight of daily solid waste.

The data gathered from each household contributing to the survey were further analyzed and the features of waste products were determined.

\section{QUESTIONNAIRE SURVEY PROCEDURE}

\begin{tabular}{|l|c|}
\multicolumn{2}{c|}{ TABLE I: OVERVIEW OF SURVEY } \\
\hline Survey period & 2014.09.01 to 2014.09.25 (24 days) \\
\hline $\begin{array}{l}\text { Survey } \\
\text { methodology }\end{array}$ & $\begin{array}{l}\text { 1. Interview by face to face meeting } \\
\text { 2. Questionnaire distribution } \\
\text { 3. Classification of solid products in } \\
\text { households }\end{array}$ \\
\hline $\begin{array}{l}\text { Collected data } \\
\text { sources }\end{array}$ & $\begin{array}{l}\text { 1. } 400 \text { residents } \\
\text { 2. 18 households }\end{array}$ \\
\hline Objective & To identify an efficient waste management system \\
\hline $\begin{array}{l}\text { Survey content } \\
\text { objectives }\end{array}$ & $\begin{array}{l}\text { To collect complete information on waste amounts, } \\
\text { sizes and types. }\end{array}$ \\
\hline
\end{tabular}

The purpose of the Questionnaire survey was to collect data about Mongolian solid waste data from the selected households. Table I lists the overview of the overall survey.

$77 \%$ out of the 400 residents who participated in the survey live in "Ger" and $23 \%$ of the participants live in modern apartments. The number of inhabitants, their ages and their monthly income are listed in Table II.

TABLE II: SURVEY PARTICIPANTS’ AGE, NUMBER AND HOUSEHOLD INCOME

\begin{tabular}{|c|c|c|c|c|c|}
\hline \multicolumn{2}{|c|}{} & \multicolumn{2}{|c|}{ Family Members } & \multicolumn{2}{|c|}{ Household Income } \\
\hline Age & $\%$ & Individuals & $\%$ & Mongolian tugrug & $\%$ \\
\hline \begin{tabular}{c}
\hline 20 \\
under
\end{tabular} & 21 & 1 & 0.5 & under 150,000 & 1 \\
\hline $21-30$ & 25 & 2 & 7.4 & $150,000-300,000$ & 3 \\
\hline $31-40$ & 17 & 3 & 19.6 & $300,100-600,000$ & 11 \\
\hline $41-50$ & 12 & 4 & 25.7 & $600,100-900,000$ & 15 \\
\hline $51-60$ & 12 & 5 & 24 & $900,100-1,200,000$ & 15 \\
\hline $61-70$ & 5 & 6 & 12 & $1,200,100-1,500,000$ & 8 \\
\hline $71-80$ & 0.6 & 7 & 5.4 & $1,500.000-2,000,000$ & 5 \\
\hline NA & 7.4 & 8 & 2.2 & above 2,000,000 & 6 \\
\hline & & NA & 2.2 & NA & 35 \\
\hline
\end{tabular}

Out of the total 400 survey participants, $52 \%$ stated that disposal of plastic bags is high, $36 \%$ for pet bottles, $23 \%$ for glass, $19-26 \%$ for cans, and $14-23 \%$ for ash, all of which are thrown outdoors, polluting the environment as shown in Fig. 1.

As for responses to questions identifying the reasons of throwing garbage outdoors, residents cited lack information about garbage disposal, but $34-43 \%$ of habitants said they are just lazy. 29-32\% replied that there is a lack of garbage bins and $10-14 \%$ responded that the garbage truck does not come on time for pickup or there are no disposal centers.

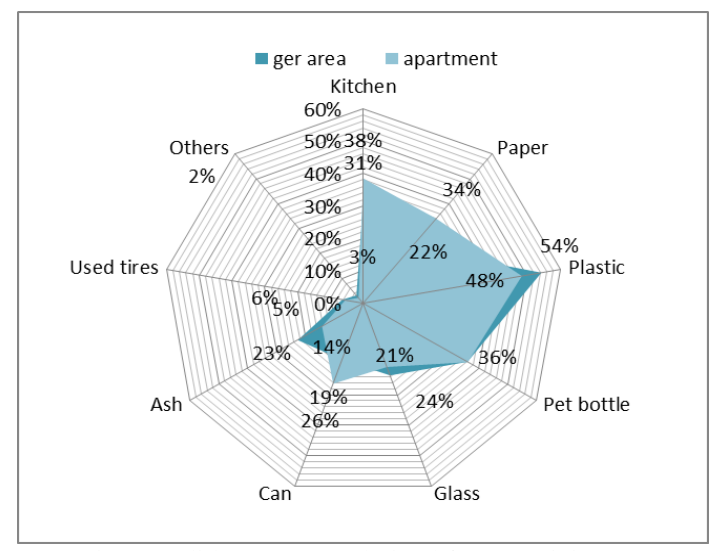

Fig. 1. Solid waste rates derived from participants.

The amount of solid waste generated from the households is listed in Table III. As listed in the table, pet bottles occupied maximum volume among all kinds of solid waste. The amount of waste depends on the season, as shown in table.

Based on the interviews at industrial sites and companies, it can be stated that bars, restaurants, cooking shops and kindergartens produce 50 kilograms of waste on average, $60-85 \%$ of which is bottles, cans, plastic bottles and other 
recyclable waste products. Classification of waste products in households and companies will certainly contribute to the development of recycling facilities. Likewise, a government policy to promote recyclable package products will make a big difference in reducing the amount of waste.

TABLE III: HOUSEHOLD SOLID WASTE GENERATION IN WINTER AND SUMMER

\begin{tabular}{|l|c|c|c|c|}
\hline \multirow{3}{*}{$\begin{array}{l}\text { Waste in } \\
\text { environment }\end{array}$} & $\begin{array}{c}\text { Summer } \\
\%\end{array}$ & $\begin{array}{c}\text { Winter } \\
\%\end{array}$ & $\begin{array}{c}\text { Summer } \\
\%\end{array}$ & $\begin{array}{c}\text { Winter } \\
\%\end{array}$ \\
\cline { 2 - 5 } & 33 & 35 & 40 & 37 \\
\hline Kitchen waste & 8 & 11 & 9 & 15 \\
\hline Bone & 20 & 18 & 20 & 20 \\
\hline Waste paper & 40 & 36 & 38 & 32 \\
\hline Plastic & 50 & 19 & 45 & 24 \\
\hline Pet bottles & 19 & 12 & 21 & 14 \\
\hline Glass & 20 & 10 & 21 & 11 \\
\hline Cans & 5 & 3 & 6 & 3 \\
\hline Other & & 40 & & \\
\hline Ash & & & & \\
\hline
\end{tabular}

TABLE IV: AMOUNT OF WASTE GENERATED IN A HOUSEHOLD PER DAY

\begin{tabular}{|l|l|l|l|l|l|l|}
\hline Waste & \multicolumn{2}{|c|}{ Ger Area } & \multicolumn{2}{r|}{ Apartments } & \multicolumn{2}{c|}{ Total amounts } \\
\hline & $\mathrm{kg}$ & $\%$ & $\mathrm{~kg}$ & $\%$ & $\mathrm{~kg}$ & $\%$ \\
\hline Kitchen & 0.472 & 53.2 & 1.410 & 84.7 & 1.882 & 74.3 \\
\hline Pet bottles & 0.021 & 2.4 & 0.019 & 1.1 & 0.040 & 1.6 \\
\hline Glass & 0.040 & 4.6 & 0.049 & 2.9 & 0.089 & 3.5 \\
\hline Cans & 0.002 & 0.2 & 0.001 & 0.1 & 0.003 & 0.1 \\
\hline Plastic & 0.036 & 4.0 & 0.010 & 0.6 & 0.045 & 1.8 \\
\hline Paper & 0.040 & 6.8 & 0.046 & 2.8 & 0.086 & 3.4 \\
\hline Other & 0.255 & 28.8 & 0.130 & 7.8 & 0.385 & 15.2 \\
\hline Total & 0.886 & 100 & 1.665 & 100 & $\mathbf{2 . 5 3 2}$ & 100 \\
\hline
\end{tabular}

\section{RESUlTS AND DisCUSSION}

A household generates $2.53 \mathrm{~kg}$ of waste on average per day as shown in Table IV. $74.3 \%$ out of all daily waste is kitchen waste, $1.6 \%$ is pet bottles, $3.5 \%$ glass, $0.1 \%$ cans, $1.8 \%$ plastic bags, $3.4 \%$ cartons and paper, and the remaining $15.2 \%$ miscellaneous junk.

1.6 L of pet bottles, $0.2 \mathrm{~L}$ of glass containers, and 3 plastic bags are generated on average per day, and 1 can is generated every 2 days per household.

Taking into consideration the weight of all recyclable waste products, it can be assumed that the amount of $500 \mathrm{ml}$ pet bottles is equal to 18 grams, $330 \mathrm{ml}$ glass containers total 210 grams, and $330 \mathrm{ml}$ cans are equal to 12.73 grams. In consideration of the fact that 333,379 households were in Ulaanbaatar City as of 2013 , it can be derived that there are 832,500 individual items of $1.5 \mathrm{~L}$ pet bottles, $0.2 \mathrm{~L}$ glass containers and cans may be generated and transported to open dump sites each day. Scavengers will then collect the recyclable items from the open dump sites within a few days. Although $3.2 \%$ of all recyclable wastes are collected by the scavengers, the other $96.8 \%$ of recyclable items remain in the dump sites and pollute the soil and air. In addition, if the remaining recyclable wastes such as cans, pet bottles and plastic bags were to be classified and transported to the recycling plants, this would result in economic profit. Some researches have shown that selective collection costs may represent $70 \%$ of the total cost of MSW management and can vary depending on the pre-collection system applied [7].

However, recyclable waste constitutes $11 \%$ of all waste products and that occupies only a small portion of the waste generated by households. In contrast, the total volume of recyclable waste is 3 times larger than the remaining mixed waste. It is possible to reduce the amount of total solid waste by $30-40 \%$, if the recyclable wastes are classified and pre-collected.

\section{CONCLUSION}

From the results of the survey, it can be concluded that environment pollution in Ulaanbaatar City strongly depends on the municipal waste management efforts. In order to reduce the amount of mixed waste, it is better to control waste pre-collection procedures such as classification of waste for households and enterprises.

The results of this research have identified the solid waste amounts, composition patterns/types and features of waste in Ulaanbaatar. Despite the low percentage of recyclable waste for the city, the amount is three times the normal waste accumulation for loss-generating transportation. Separating the recyclable garbage before transportation to dumping sites reduces the amount of garbage transported by $30-40 \%$, lowering transportation costs and environmental pollution.

Though this research focused on households, in the future the research will focus on enterprises' and factories' recyclable garbage disposal amounts, categories, distinctive features, collection, transportation, recycling management and direction identification, economic cycles, and accounting profitability. There are few waste recycling plants starting operation. Unfortunately, due to the lack of a nationwide policy for classifying the waste, these facilities are facing difficulties in collecting, accumulating and transporting those recyclable raw materials. Therefore, recycling factories increase total costs, and this has become the main reason for poor development and management plans.

Health and safety concerns for those who work at the hazardous open dumps are key problems that need to be solved in the city. In some developed countries, people who have the ability to classify the wastes are given opportunities to work at the waste handling factories, in order to solve the related social issues.

\section{ACKNOWLEDGMENT}

The authors would like to express sincere thanks to all people who participated in the survey.

\section{REFERENCES}

[1] E. Shinee, E. Gombojav, A. Nishimura, N. Hamajima, and K. Ito, "Healthcare waste management in the capital city of Mongolia," Waste Management, vol. 28, no. 2, pp. 435-441, 2008.

[2] K. Yoshiaki, "Environment problems in Mongolia's urban area," Journal of Eco technology Research, vol. 14, no. 2, p. 53, 2008.

[3] M. Ali and C. Kuroiwa, "Status and challenges of hospital solid waste management: Case studies from Thailand, Pakistan, and Mongolia," Journal of Material Cycles and Waste Management, vol. 11, no. 3, pp. 251-257, 2009.

[4] D. Altantuya, Z. Zhang, and H. Li, "Municipal solid waste management of Mongolia: Analysis on the solid waste treatment of 
Ulaanbaatar city," Advances in Asian Social Science (AASS), vol. 3, no. 3, 2012.

[5] B. Bolorchimeg, "Comparative analysis of solid waste management in ulaanbaatar, Mongolia: Sustainability assessment and its implications," Dept. of Environment, Hokkaido Univ., Hokkaido, Japan, 2012.

[6] Final Report of the International Internship in Mongolia, Environmental Diplomatic Leader Education Program, Univ. of Tsukuba., Japan, 2012.

[7] A. Gallardo, M. Carlos, M. Peris, and F. J. Colomer, "Methodology to design a municipal solid waste pre-collection system: A case study," Waste Managements, vol. 36, pp. 1-11, 2015.

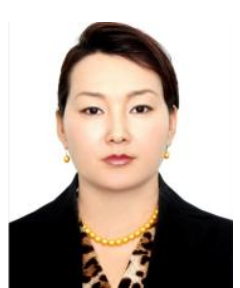

Gombojav Delgermaa was born on May 27, 1974 in Ulaanbaatar city of Mongolia. She was awarded the bachelor degree of management in eco tourism from the International Tourism Management Institute of Mongolia in 2002. From 2002 until 2008, she worked as a research assistant in the Department of Environment of the International Tourism Management Institute of Mongolia. From 2008 until 2011, she was an expert of Environmental Protection Association of Mongolia. She is a master degree student in the Department of Life and Environmental Engineering, Faculty of Environmental Evaluation and Management of Social Systems and Theory of Eco-Industrial Parks (EIP) of the University of Kitakyushu from 2014 until present.

Ms. Delgermaa's research area is the environmental engineering such as solid waste management. She is conducting research on Mongolian waste management of households.

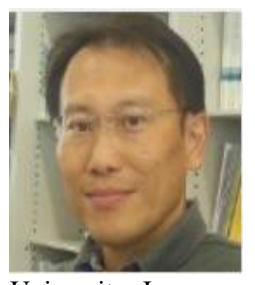

Toru Matsumoto is a professor of the University of Kitakyushu, Japan. Prof. Matsumoto was born in 1967 in Yamaguchi prefecture of Japan. He received his bachelor degree of engineering in environmental systems analysis in 1990, the master degree of engineering in environmental science in 1992 and awarded the degree of doctor of engineering in environmental systems analysis in 1999 from Kyushu

University, Japan

He worked as a researcher for Nomura Research Institute (NRI), where is one of the biggest think tank in Japan, between 1992 and 1995. He was a research associate of Kyushu University from 1995 until 1999 and an associate professor of Kyushu University and the University of Kitakyushu from 2000 until 2008. From 2008 until present, he is a professor of the Department of Life and Environmental Engineering, Faculty of Environmental Evaluation and Management of Social Systems and Theory of Eco-Industrial Parks (EIP) of the University of Kitakyushu. Prof. Matsumoto has published over 40 scientific papers in Japanese and international professional journals. The thesis prize was won the Japan Society of Civil Engineers in 1998. The encouragement prize was won from Society of Environmental Science, Japan in 2005. The thesis was won from the Japan Association for Human and Environmental Symbiosis in 2007.

Prof. Matsumoto is member of several professional societies such as: International Society of Industrial Ecology (ISIE), Japan Society of Civil Engineering (JSCE), etc. 